\title{
Radioimmunotherapy for CD133(+) colonic cancer stem cells inhibits tumor development in nude mice
}

\author{
Weng Dinghu ${ }^{1,2}$, Jin Xueyan ${ }^{1,2}$, Qin Saimei, ${ }^{1,2}$, Lan Xiaoli, ${ }^{1,2}$, Chen Chong ${ }^{1,2}$, Sun \\ Xun $^{1,2}$, She Xianliang ${ }^{1,2}$, Dong Changling ${ }^{3}$ and An Rui ${ }^{1,2}$ \\ ${ }^{1}$ Department of Nuclear Medicine, Union Hospital, Tongji Medical College, Huazhong University of Science and Technology, \\ Wuhan 430022, China \\ ${ }^{2}$ Hubei Key Laboratory of Molecular Imaging, Union Hospital, Tongji Medical College, Huazhong University of Science and \\ Technology, Wuhan 430022, China \\ ${ }^{3}$ Department of Neurosurgery, Renmin Hospital, Hubei University of Medicine, Shiyan 442000, China \\ Correspondence to: An Rui, email: An_NM0929@163.com \\ Keywords: radioimmunotherapy, cancer stem cells, CD133, iodine-131, N-succinimidyl 3- (tri-n-butylstannyl) benzoate \\ Received: October 11, $2016 \quad$ Accepted: March 14, $2017 \quad$ Published: April 06, 2017 \\ Copyright: Dinghu et al. This is an open-access article distributed under the terms of the Creative Commons Attribution License 3.0 \\ (CC BY 3.0), which permits unrestricted use, distribution, and reproduction in any medium, provided the original author and source \\ are credited.
}

\section{ABSTRACT}

Accumulating evidence indicates that cancer stem cells (CSCs) are the cause of tumor drug/radio-resistance or distant metastasis; therefore, it is essential to eliminate CSCs to cure cancer completely. The purpose of this study was to utilize radioimmunotherapy (RIT) to target CD133(+) colonic CSCs and observe whether this prevented tumor development, by assessing the maximum tolerated dose (MTD) of HCT116 tumor-bearing nude mice with escalating doses of ${ }^{131}$ I-AC133.1 monoclonal antibody (mAb), and determining the therapeutic efficacy of RIT with ${ }^{131}$ I-AC133.1 mAb. For RIT trials, animals were randomly divided into 4 groups of 6 per group, and injected with ${ }^{131} \mathrm{I}-\mathrm{AC} 133.1 \mathrm{mAb}(16.65 \mathrm{MBq} / 100 \mu \mathrm{l})$, AC133.1 mAb $(173.1 \mu \mathrm{g} / 100 \mu \mathrm{l})$, saline $(100$ $\mu \mathrm{I})$, or unrelated IgG1 as an isotype control. Iodine-131 was radiolabeled to AC133.1 mAb by conjugation with $\mathrm{N}$-succinimidyl 3-(tri-n-butylstannyl) benzoate. The MTD of HCT116 tumor-bearing nude mice was $16.65 \mathrm{MBq}$. Both of the tumor volume doubling time and the survival time of the ${ }^{131}$ I-AC133.1 mAb group were significant longer than other groups $(P<0.001)$. CD133 expression was assessed by flow cytometry. Protein levels of cancer stem-like biomarkers (CD133, ALDH1, Lgr5, Vimentin, Snail1), and the proliferative rate of ${ }^{131}$ I-AC133.1 mAb group were lower than other groups $(P<0.001)$; while its protein level of E-cadherin was higher than other groups. Furthermore, a large proportion of tumor necrosis was also observed in the ${ }^{131} \mathrm{I}-\mathrm{AC} 133.1 \mathrm{mAb}$ group, suggesting that RIT can destroy CSCs and effectively inhibit tumor development.

\section{INTRODUCTION}

Colorectal cancer (CRC) is the second and third most common cancer worldwide in females and males, respectively [1]. It has the fifth highest cancer mortality rate in China and is the third leading cause of cancer death in the United States $[2,3]$. The five-year survival rate of CRC was less than 70\%, although neo-adjuvant chemotherapy has been improved [4], failure of anti-cancer therapy is attributed to a subpopulation of cells called cancer stem cells (CSCs) [5, 6].

CSCs play an important role in maintaining tumor growth through their unlimited self-renewal, therapeutic resistance, and the capacity to propagate tumors through asymmetric cell division [7]. Since CSCs were firstly isolated in acute myeloid leukemia [8], many CSCs of solid tumors, including breast, brain, lung, colon cancers as well as melanoma, have been identified [7]. Cell surface markers have been intensively used to isolate and identify CSCs, of which CD133 is frequently acknowledged as a CSC marker. CD133, also known as Prominin-1, is a 120$\mathrm{kDa}$ cholesterol-interacting pentaspan-transmembrane glycoprotein that belongs to the Prominin family [9]. CD133 was first reported to be a CSC marker for brain tumors by Singh et al. [10,11], following which O'Brien et al. [12] 
demonstrated that colonic CSCs within the CD133(+) population have stem cell potential, allowing selfmaintenance and differentiation as well as reestablishing tumor heterogeneity upon serial transplantation.

Eradication of CSCs is critical for improvement in tumor prognosis [7, 13]. Various strategies have been proposed to target CSCs, including an antigen-based approach and inhibition of pathways related to selfrenewal, maintenance and drug resistance of CSCs [14]. The antigen based approach relies on specific markers expressed on CSCs, with cognate antibody conjugated to drugs such as 5-Fluorouracil or radionuclide which could enhance the therapeutic effect of antibody-based immunotherapy alone. Jandal et al. [15] used ${ }^{188}$ Re-labeled anti-melanin monoclonal antibody $(\mathrm{mAb}) 6 \mathrm{D} 2$ for the treatment of mice bearing A2058 melanoma xenograft, indicating a similar rate of killing of melanoma stem cells and bulk cells. Then, Leyton et al. [16] utilized a radiolabeled antibody to target leukemia stem cells directly, demonstrating that high dose radioimmunotherapy (RIT) reduced leukemia stem cell viability and impaired self-renewal. Moreover, AI-Ejeh et al. [17] reported that ${ }^{177} \mathrm{Lu}$ labeled anti-EGFR mAb alone significantly reduced the percentage of $\mathrm{CD} 44(+) / \mathrm{CD} 24(-) / \operatorname{EpCAM}(+)$ breast CSCs, especially when combined with chemotherapy and a poly ADP-ribose polymerase inhibitor. These findings suggest RIT has a potential advantage for targeting CSCs. To date, two products, Zevalin ( ${ }^{90} \mathrm{Y}$-ibritumomab tiuxetan) and Bexxar ( ${ }^{131} \mathrm{I}$-tositumomab) have been approved for the treatment of non-Hodgkin B-cell lymphoma in the clinic.

Beta $(\beta)$-emitters are commonly used for RIT based on their unique characteristics: radiolabeled antibodies conjugated to $\beta$-emitters can kill surrounding cells by a bystander "cross-fire" effect, which is independent of the expression of the target antigen or the sensitivity of the cells to chemotherapeutic drugs [18]. The physical properties of iodine-131 ( $\left.{ }^{131} \mathrm{I}\right)$ have allowed it to be widely used for RIT. However, dehalogenation is the main drawback of antibody radioiodination using the Iodogen method [19], which can decrease the stability of labeled antibody in vivo and cause radioactive damage to the thyroid. A potential factor contributing to the dehalogenation of proteins in vivo is the recognition of labeled iodophenyl groups on the protein by deiodiases known to be involved in the metabolism of thyroid hormones [20]. Santous et al. [21] verified that retention labeling such as N-succinimidyl 3-(tri-n-butylstannyl) benzoate (ATE) method have a fast blood clearance, better target organ/background relation and low uptake in the thyroid and stomach compared with the direct labeling method. Our previous work utilized ${ }^{131}$ I labeled AC133.1 $\mathrm{mAb}$ to trace CD133(+) colonic CSCs in vivo [22], which established a foundation for RIT of CSCs. In this study, we attempted to target CD133(+) colonic CSCs with RIT.

\section{RESULTS}

\section{MAb characterization}

The retention time of $\mathrm{N}$-succinimidyl $3-\left[{ }^{131} \mathrm{I}\right]$ iodobenzoate $\left({ }^{131} \mathrm{I}-\mathrm{SIB}\right)$ was approximately $11.0 \mathrm{~min}$ (data not shown), and generated about $88.0 \%$ yield and 60.4 to $76.6 \%$ of this intermediate was coupled to AC133.1 $\mathrm{mAb}$ following a $30 \mathrm{~min}$ reaction at room temperature (RT). The radiospecific activity of ${ }^{131} \mathrm{I}-\mathrm{AC} 133.1 \mathrm{mAb}$ was $77.70 \mathrm{KBq} / \mu \mathrm{g}$ to $96.20 \mathrm{KBq} / \mu \mathrm{g}$, Scatchard analyses of the binding data revealed that the equilibrium dissociation constant $\mathrm{K}_{\mathrm{D}}$ for AC133.1 mAb was $(4.76 \pm 0.30) \times 10^{-8} \mathrm{M}$, and the nonspecific binding was less than $2 \%$.

The radiochemical purity of the labeled antibody was $94.05 \pm 1.53 \%$ and it was $87.64 \pm 0.33 \%$ at day 7 in fetal bovine serum (FBS) (Figure 1).

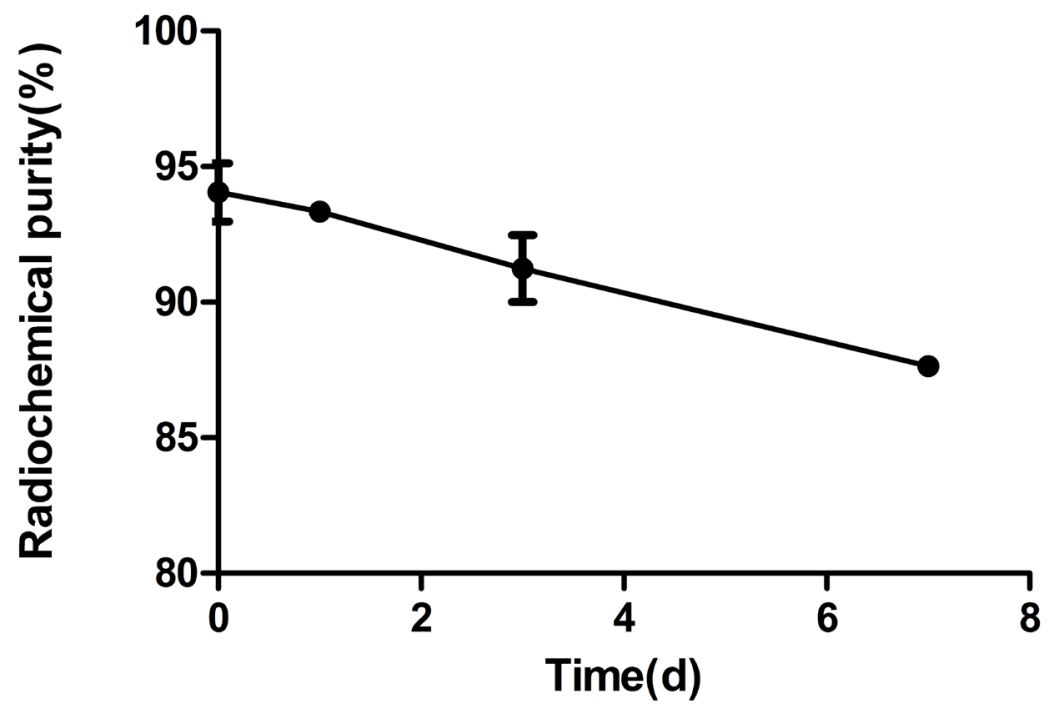

Figure 1: The stability of ${ }^{131} \mathbf{I}$-AC133.1 mAb in FBS. The radiochemistry purity of ${ }^{131} \mathrm{I}$-AC133.1 mAb at different time points $(0$, $1,3$, and $7 \mathrm{~d})$. 


\section{Does escalation and toxicity evaluation}

For the doses $7.40,9.25,11.10,12.95$ and 14.80 $\mathrm{MBq}$, there were no related deaths or loss of weight exceeding $20 \%$ of its initial. At the $16.65 \mathrm{MBq}$ dose, two mice showed temporary weight loss in the first two weeks, but this did not exceed $20 \%$. There was one case of discomfort and weight loss exceeding $20 \%$ at day 18 at a dosage of $18.50 \mathrm{MBq}$. However, for the doses of 20.35 and $22.20 \mathrm{MBq}$, animals were showed weight loss greater than $20 \%$ or death within $20 \mathrm{~d}$. Based on these results, we determined the maximum tolerated dose (MTD) of HCT116 bearing-nude mice was $16.65 \mathrm{MBq}$.

\section{Therapeutic response}

Initial tumor sizes at the time of treatment ranged from $33.07 \pm 4.94 \mathrm{~mm}^{3}$ (diameter $\sim 4 \mathrm{~mm}$ ), but the difference in tumor volume and weight of tumor-bearing nude mice were not statistically significant between the groups. From the results of tumor growth curve (Figure $2 \mathrm{~A}$ ), we conducted the tumor volume doubling time (VDT) of the four groups. A statistically significant difference was observed for tumor VDT between the ${ }^{131} \mathrm{I}$ AC133.1 mAb group and other three groups $(P<0.001)$, with a value of $9.36 \pm 0.45$ days for the ${ }^{131} \mathrm{I}-\mathrm{AC} 133.1 \mathrm{mAb}$ group, and $6.29 \pm 0.78$ days, $6.42 \pm 0.35$ days and $6.89 \pm$ 0.30 days for saline, ${ }^{131} \mathrm{I}-\mathrm{IgG} 1$ and $\mathrm{AC} 133.1 \mathrm{mAb}$ groups, respectively. There were no significant differences among the other groups $(\mathrm{P}=0.071)$. From the survival curve (Figure 2B), we calculated the median survival time of each group, and they were $44.0 \mathrm{~d}, 27.8 \mathrm{~d}, 29.4 \mathrm{~d}, 32.6 \mathrm{~d}$ for ${ }^{131} \mathrm{I}$-AC133.1 mAb, Saline, ${ }^{131} \mathrm{I}$-IgG1, AC133.1 mAb groups, respectively; and the survival time of ${ }^{131} \mathrm{I}-\mathrm{AC} 133.1$ $\mathrm{mAb}$ group was longer than the other groups $(P<0.001)$,

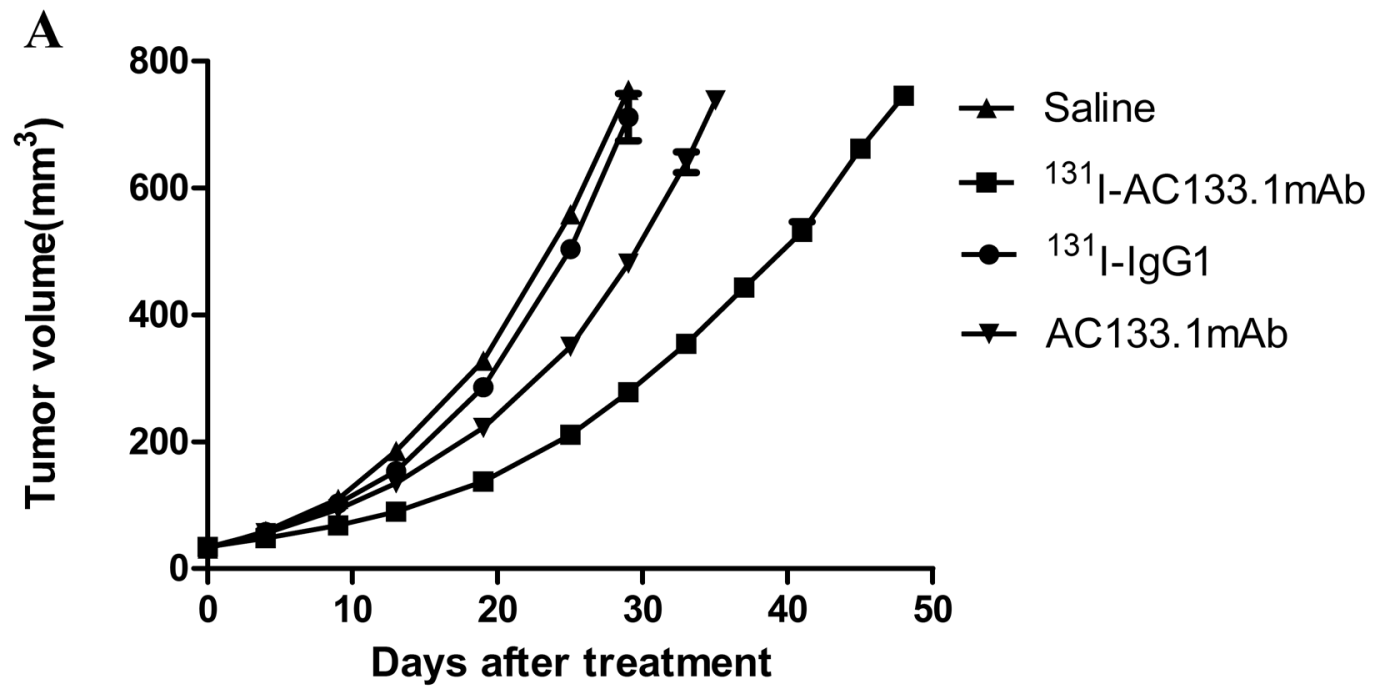

B

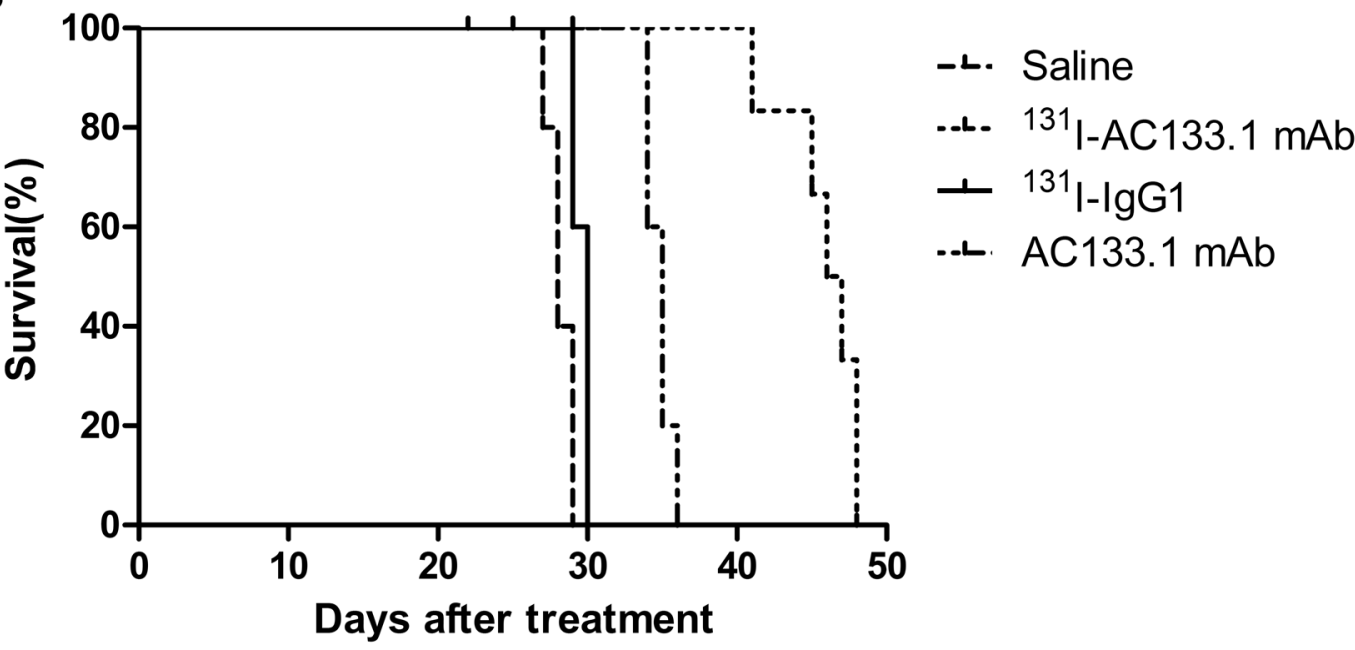

Figure 2: Tumor growth curves (A) and survival curves (B) of the four groups. Initial tumor sizes at the time of treatment ranged from $33.07 \pm$ $4.94 \mathrm{~mm}^{3}$ (diameter $\sim 4 \mathrm{~mm}$ ), both the tumor VDT (A) and the survival time (B) of ${ }^{131} \mathrm{I}$-AC133.1 $\mathrm{mAb}$ group were longer than the controls $(P<$ $0.001)$; there were no significant differences for $\operatorname{VDT}(\mathrm{P}=0.071)$ and survival time $(\mathrm{P}=0.420)$ among the controls. 
Table 1: The biodistribution of ${ }^{131} \mathrm{I}-\mathrm{AC} 133.1 \mathrm{mAb}$ in HCT116 tumor-bearing nude mice (Data were shown as mean \pm $\mathrm{SD}, \% \mathrm{ID} / \mathrm{g}, \mathrm{n}=4)$

\begin{tabular}{|c|c|c|c|c|c|}
\hline Tissue & 1 day & 3 day & 5 day & 7 day & 9 day \\
\hline Tumor & $4.63 \pm 0.07$ & $8.69 \pm 0.34$ & $7.28 \pm 0.11$ & $6.52 \pm 0.16$ & $3.15 \pm 0.16$ \\
\hline Blood & $16.87 \pm 0.60$ & $10.72 \pm 1.80$ & $8.20 \pm 0.21$ & $7.48 \pm 0.66$ & $4.77 \pm 0.58$ \\
\hline Femoral bone & $1.88 \pm 0.31$ & $1.31 \pm 0.36$ & $1.15 \pm 0.19$ & $0.76 \pm 0.03$ & $0.70 \pm 0.03$ \\
\hline Muscle & $1.23 \pm 0.12$ & $0.97 \pm 0.29$ & $0.81 \pm 0.17$ & $0.60 \pm 0.09$ & $0.35 \pm 0.04$ \\
\hline Liver & $8.62 \pm 0.48$ & $9.51 \pm 0.72$ & $7.91 \pm 0.71$ & $5.35 \pm 0.82$ & $2.58 \pm 0.37$ \\
\hline Kidney & $2.58 \pm 0.37$ & $9.97 \pm 0.76$ & $5.74 \pm 0.74$ & $4.07 \pm 0.87$ & $1.99 \pm 0.10$ \\
\hline Intestine & $1.16 \pm 0.08$ & $1.27 \pm 0.19$ & $0.91 \pm 0.12$ & $0.67 \pm 0.11$ & $0.41 \pm 0.10$ \\
\hline Spleen & $6.51 \pm 0.34$ & $6.63 \pm 0.44$ & $2.83 \pm 0.16$ & $2.44 \pm 0.06$ & $1.21 \pm 0.06$ \\
\hline Stomach & $1.14 \pm 0.02$ & $1.12 \pm 0.11$ & $0.99 \pm 0.04$ & $0.66 \pm 0.04$ & $0.43 \pm 0.08$ \\
\hline Lung & $8.48 \pm 1.16$ & $5.31 \pm 0.86$ & $4.51 \pm 0.15$ & $3.94 \pm 0.45$ & $2.43 \pm 0.30$ \\
\hline Heart & $4.70 \pm 0.04$ & $2.73 \pm 0.60$ & $1.83 \pm 0.09$ & $1.28 \pm 0.18$ & $0.82 \pm 0.05$ \\
\hline Thyroid & $0.99 \pm 0.12$ & $0.82 \pm 0.05$ & $0.74 \pm 0.01$ & $0.35 \pm 0.05$ & $0.34 \pm 0.03$ \\
\hline Brain & $0.60 \pm 0.10$ & $0.37 \pm 0.12$ & $0.30 \pm 0.06$ & $0.22 \pm 0.06$ & $0.17 \pm 0.03$ \\
\hline Tumor/muscle & $3.78 \pm 0.30$ & $9.51 \pm 2.46$ & $9.24 \pm 1.73$ & $7.80 \pm 1.42$ & $6.63 \pm 1.14$ \\
\hline Tumor/thyroid & $4.69 \pm 0.50$ & $10.65 \pm 0.74$ & $9.79 \pm 0.08$ & $19.12 \pm 3.21$ & $9.26 \pm 0.29$ \\
\hline Tumor/blood & $0.28 \pm 0.03$ & $0.82 \pm 0.12$ & $0.89 \pm 0.04$ & $0.88 \pm 0.09$ & $0.66 \pm 0.04$ \\
\hline
\end{tabular}

there were no significant differences among the controls $(\mathrm{P}=0.420)$

\section{Biodistribution measurement and radiation dosimetry}

The highest ratio of tumor/thyroid was $19.12 \pm$ 3.21 at day 7 , which was higher compared with our previous study using the Iodogen method. Nontarget organs such as muscle, bone, gastrointestinal, lungs, and heart all maintained low levels of ${ }^{131} \mathrm{I}-\mathrm{AC} 133.1 \mathrm{mAb}$. From the biodistribution data (Table 1), we calculated the accumulated radiation dosimetry of tumor in ${ }^{131} \mathrm{I}-\mathrm{AC} 133.1 \mathrm{mAb}$ group to be 5,966.34 $\pm 54.90 \mathrm{cGy}$.

\section{Flow cytometry, western blot (WB), hematoxylin and eosin $(\mathrm{H} \& \mathrm{E})$ and Ki67 staining}

CD133 expression in the ${ }^{131} \mathrm{I}-\mathrm{AC} 133.1 \mathrm{mAb}$ group was $7.15 \pm 0.95 \%$, which was significant lower than the controls (saline group: $21.70 \pm 1.61 \%,{ }^{131} \mathrm{I}-\mathrm{IgG} 1$ group: $20.12 \pm 1.46 \%$, AC133.1 mAb group: $18.24 \pm 2.53 \%)(P<$ $0.001)$ (Figure 3 ), and there were no significant differences among the controls $(\mathrm{P}=0.244)$. Protein levels cancer stemlike biomarkers (CD133, ALDH1, Lgr5, E-cadherin, Vimentin, Snail1) were also tested, indicating that the expression of CD133, ALDH1, Lgr5, Vimentin and Snail1 in the ${ }^{131} \mathrm{I}-\mathrm{AC} 133.1 \mathrm{mAb}$ group were lower than the other groups, while the level of E-cadherin was higher (Figure 4). Ki67 analysis showed reduced proliferative index in the ${ }^{131} \mathrm{I}-\mathrm{AC} 133.1 \mathrm{mAb}$ group $(9.52 \pm 1.33 \%)$, whereas the ${ }^{131} \mathrm{I}-\mathrm{IgG} 1, \mathrm{AC} 133.1 \mathrm{mAb}$, saline groups had significantly higher proliferative indices $(37.46 \pm 3.72 \%$, $32.60 \pm 2.88 \%, 45.56 \pm 3.52 \%$, respectively $)(P<0.001)$ (Figure 5). H\&E staining of tumor tissues showed a large necrotic area in tumors from the ${ }^{131} \mathrm{I}-\mathrm{AC} 133.1 \mathrm{mAb}$ group; however, no obvious necrosis was observed in the controls (Figure 6).

\section{DISCUSSION}

In this study, AC133.1 mAb was radioiodinated by the ATE method and showed satisfactory characteristics. The ${ }^{131}$ I-AC133.1 mAb was utilized to target CD133(+) colorectal CSCs, and analysis of the therapeutic effect (tumor VDT, median survival time, CD133 expression by flow cytometry, protein levels of cancer stem-like biomarkers, Ki67 and H\&E staining of tumors) suggested that ${ }^{131} \mathrm{I}$-AC133.1 mAb could destroy CSCs and inhibit tumor development.

There is an urgent need to eliminate CSCs based on their critical role in tumor relapse and distant metastasis after therapy; however, conventional therapeutics have no effect on CSCs due to their chemo/radio-resistance. Therefore, some studies have attempted to target CSCs with RIT. Jandl et al. [15] utilized an ${ }^{188}$ Re-6D2 antibody 
to target mice bearing A2058 melanoma xenografts, showing RIT killed the melanoma stem cells at the same rate as the other tumor cells. Later, Leyton et al. [23] applied ${ }^{111}$ In labeled anti-CD123 mAb, CSL360, modified with nuclear translocation sequence peptides to study the acute myeloid leukemia engraftment assay in the prevalent NOD/SCID mouse, demonstrating a significant decrease in CD123(+) leukemic stem cells and impaired self-renewal was achieved with high doses of RIT. Both experiments suggested that RIT may be a useful therapeutic modality for eradicating CSCs. To target CSCs, a good CSCs marker is required.

To date, many cell surface markers including CD133, CD44, EpCAM, CD24, CD29, Lgr5, CD166, Sox2, and Oct4, either separately or in combination, have been used to identify colorectal CSCs [9, 24-26]; however, CD133 is the most frequently used. O'Brien et al. [12] and Lucia et al. [27] foundthatcolonic CSCs were enriched in CD133(+) cells and that their tumorigenic ability was higher than that of CD133(-) cells, indicating CD133 could be used as a useful biomarker for colonic

A

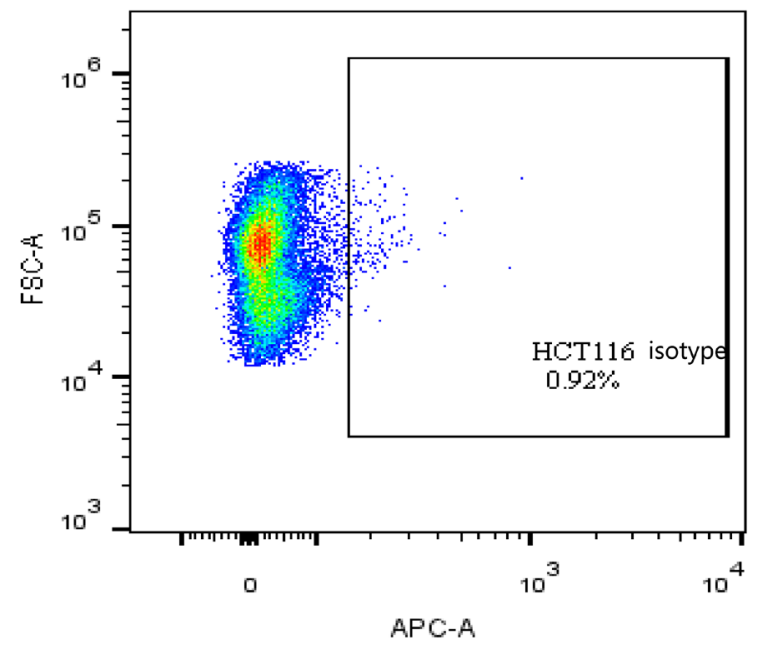

$\mathbf{C}$

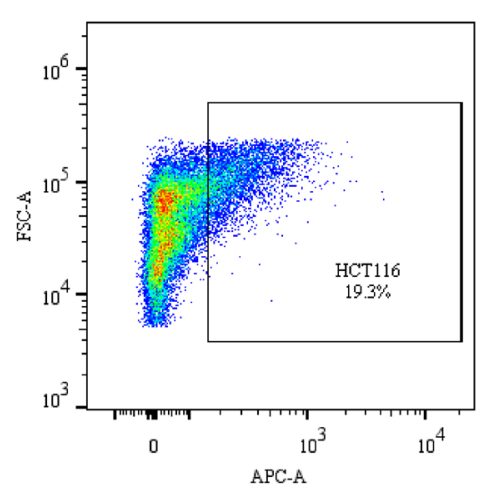

D

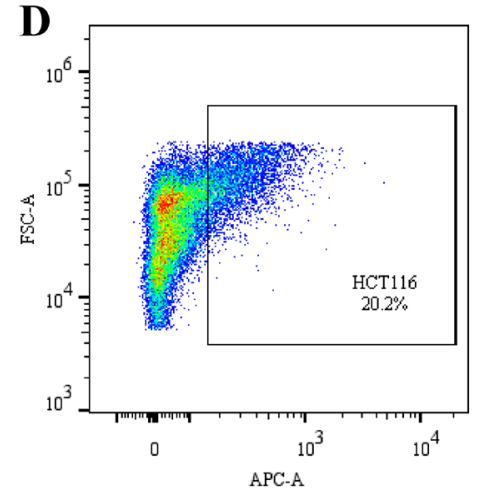

CSCs. Our previous study utilized ${ }^{131} \mathrm{I}-\mathrm{AC} 133.1 \mathrm{mAb}$ to trace CD133(+) colonic CSCs successfully in vivo [22], which laid a solid foundation for the use of RIT to target CD133(+) colonic CSCs with radioiodinated compounds.

For radioiodination $\mathrm{mAb}$, it is generally assumed that the loss of radioiodine from these proteins following their in vivo administration can be attributed to the action of dehalogenases normally involved in the metabolism of thyroid hormones [20], thus affecting the stability of the radiolabeled antibody in vivo. However, using retention labeling such as ATE method can avoid dehalogenation $[19,28]$. ATE contains an active ester that can be combined with ${ }^{131} \mathrm{I}$ quickly; the labeling rate of ${ }^{131} \mathrm{I}-\mathrm{SIB}$ was about $88.5 \%$, which allows the intermediate to conjugate with AC133.1 mAb under appropriate conditions. The radiochemistry purity of ${ }^{131} \mathrm{I}-\mathrm{AC} 133.1 \mathrm{mAb}$ was $94.05 \pm$ $1.53 \%$, and was $87.64 \pm 0.33 \%$ in FBS at day 7 , indicating the radiolabeled compound was relatively stable. In a cell saturated assay, the equilibrium dissociation $\mathrm{K}_{\mathrm{D}}$ was (4.76 $\pm 0.30) \times 10^{-8} \mathrm{M}$, revealing the radiolabeled antibody had a good affinity for its antigen. The radiospecific activity

B

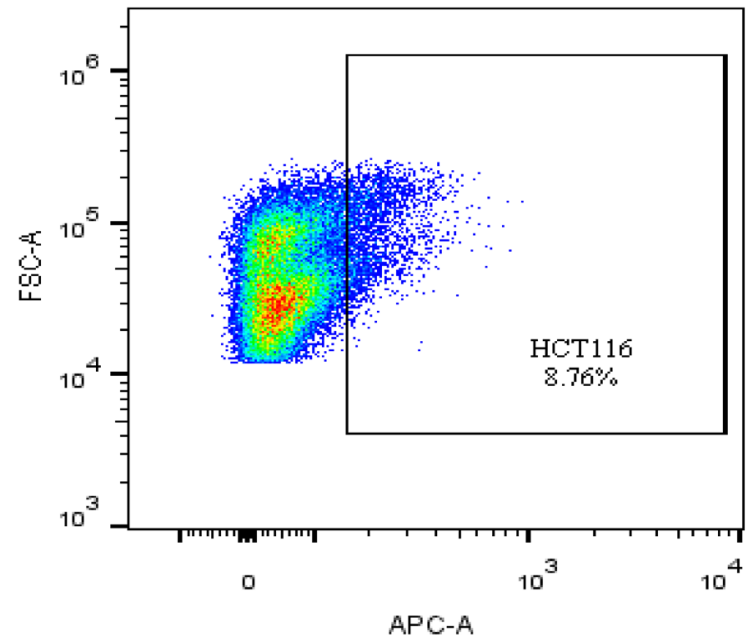

$\mathbf{E}$

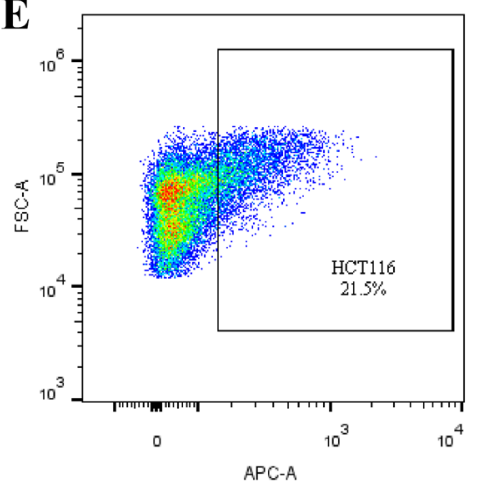

Figure 3: The CD133 expression tested by flow cytometry of the four groups. (A) Isotype control of flow cytometry. (B) ${ }^{131} \mathrm{I}-\mathrm{AC} 133.1 \mathrm{mAb}$ group, $7.15 \pm 0.95 \%$; (C) ${ }^{131} \mathrm{I}$-IgG1 group, $20.12 \pm 1.46 \%$; (D) AC133.1 mAb group, $18.24 \pm 2.53 \%$; (E) Saline group, $21.70 \pm 1.61 \%$. The CD133 expression of ${ }^{131} \mathrm{I}-\mathrm{AC} 133.1 \mathrm{mAb}$ group was lower than the controls $(P<0.001)$, and there were no significant differences among the other three groups $(\mathrm{P}=0.244)$. 


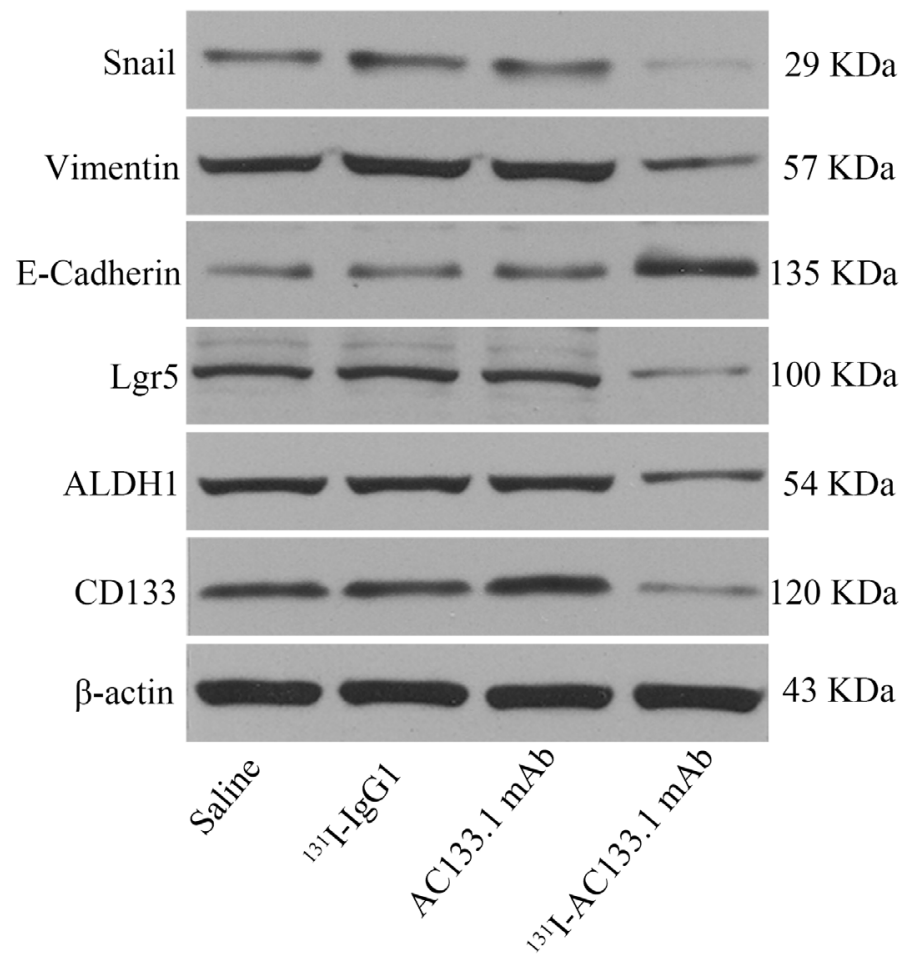

Figure 4: The protein level of cancer stem-like markers. Cancer stem-like biomarkers include CD133, ALDH1, Lgr5, E-cadherin, Vimentin, Snail1. The expression of CD133, ALDH1, Lgr5, Vimentin and Snail1 in ${ }^{131} \mathrm{I}-\mathrm{AC} 133.1 \mathrm{mAb}$ group were lower than other groups, while the level of E-cadherin was higher.

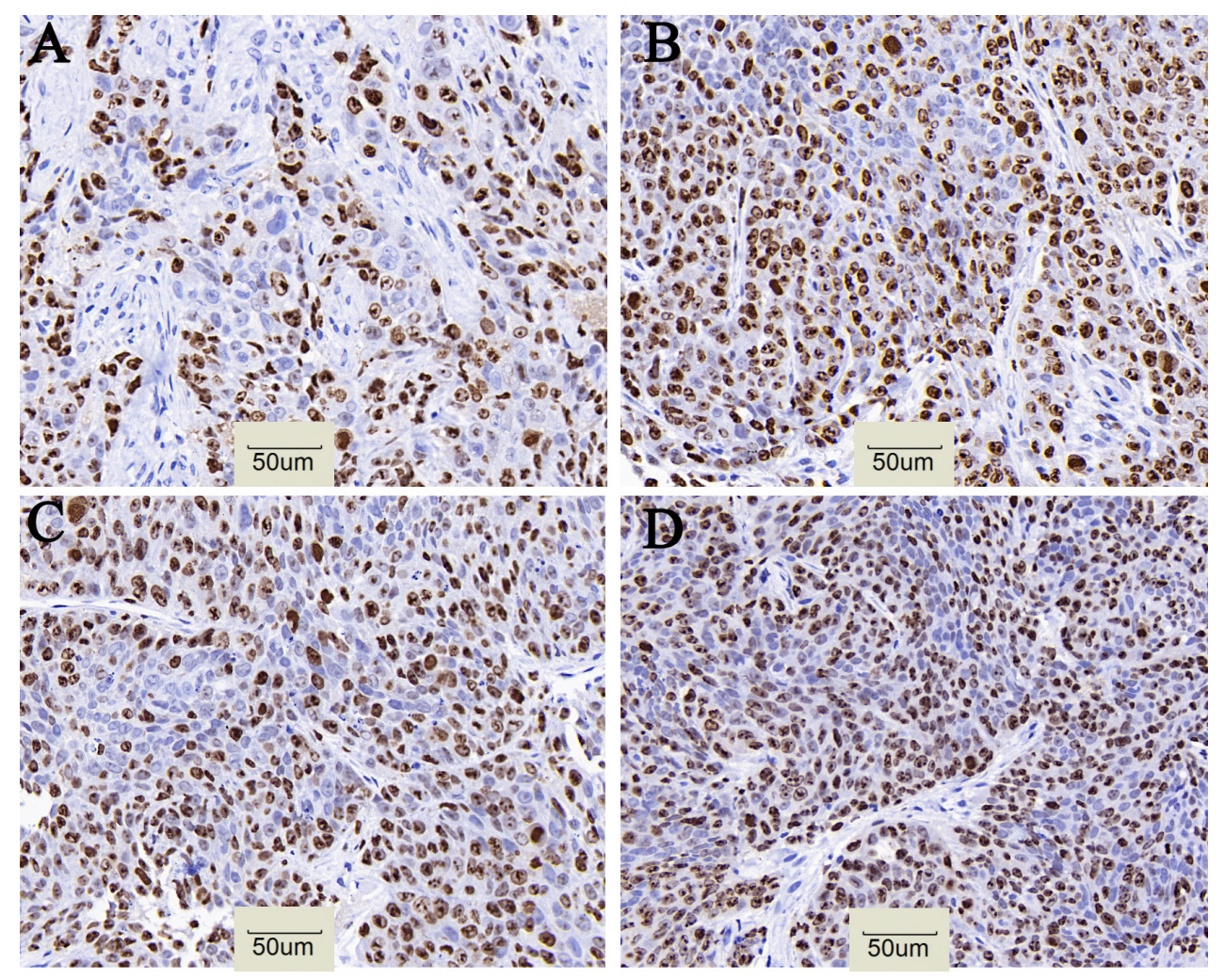

Figure 5: Cell proliferative index of tumor in four groups. (A) ${ }^{131} \mathrm{I}-\mathrm{AC} 133.1 \mathrm{mAb}$ group, $9.52 \pm 1.33 \%$; (B) ${ }^{131} \mathrm{I}-\mathrm{IgG} 1 \mathrm{group}, 37.46$ $\pm 3.72 \%$; (C) AC133.1 mAb group, $32.60 \pm 2.88 \%$; (D) Saline group, $45.56 \pm 3.52 \%$. The proliferative index of ${ }^{131} \mathrm{I}-\mathrm{AC} 133.1 \mathrm{mAb}$ group was lower than the controls $(P<0.001),(\times 200)$. 
of labeled antibody was $77.70 \mathrm{KBq} / \mu \mathrm{g}$ to $96.20 \mathrm{KBq} / \mu \mathrm{g}$, which was lower than our previous report using Iodogen method [22], as the ATE method involved a two-step reaction. Its enhanced characteristics in vitro indicated the feasible use of RIT in vivo with ${ }^{131} \mathrm{I}-\mathrm{AC} 133.1 \mathrm{mAb}$.

To choose an appropriate dosage, we performed MTD assay by assessing the health status and weight of mice. The initial dose of MTD experiment was 7.40 MBq escalating in $1.85 \mathrm{MBq}$ intervals, to a final dose of $22.20 \mathrm{MBq}$. None of the mice loss of weight exceeds $20 \%$ of its initial or died within 30 days, up to and including a dose of $16.65 \mathrm{MBq}$. However, at least one of these events emerged over a dose exceeding 16.65 MBq. We thus determined the MTD to be $16.65 \mathrm{MBq}$. For RIT experiments, the initial tumor volume was $33.06 \pm 4.98$ $\mathrm{mm}^{3}$ with a diameter of $\sim 4 \mathrm{~mm}$. This diameter was chosen because the tissue penetration of ${ }^{131} \mathrm{I}$ is less than $3 \mathrm{~mm}$ $[29,30]$, and our preliminary experiments demonstrated that the radiolabeled $\mathrm{mAb}$ had no obvious effect on tumor development if its initial volume was too large. Generally, RIT plays a role mainly dependent on the following effects: antibody dependent cellular cytotoxicity (ADCC), antigen-antibody complexes activating the complement pathway, and the killing effect of radionuclide for the targets. Radiotherapy causes DNA damage directly by ionization or indirectly via the generation of reactive oxygen species (ROS), therapy destroying the targets. As ${ }^{131} \mathrm{I}-\mathrm{AC} 133.1 \mathrm{mAb}$ could destroy CD133(+) CSCs specifically, the CD133 expression was confirmed by flow cytometry and the protein level of CD133 in ${ }^{131} \mathrm{I}-\mathrm{AC} 133.1$ $\mathrm{mAb}$ group were found to be lower than in the control groups. The percentage of CSCs was reduced, resulting in slowed tumor growth, reduced proliferative index, and longer VDT and survival time, thus supporting our hypothesis. Moreover, the protein level of other stem-like markers were tested, the expression of Lgr5, ALDH1, Vimentin and Snail1 in ${ }^{131} \mathrm{I}-\mathrm{AC} 133.1 \mathrm{mAb}$ group were lower than other observed in the other groups, while the level of E-cadherin was higher, as the expression of E-cadherin is negatively correlated with tumor invasion and metastasis. There was no obvious therapeutic effect in the $\mathrm{AC} 133.1 \mathrm{mAb}$ group; one of the reasons for this may be that in the BALB/c nude mouse model, the effect of $\mathrm{ADCC}$ alone was so weak that it could not inhibit tumor development.

To calculate the radiation dosimetry, we performed biodistribution experiments. The highest ratio of tumor/ thyroid tissue was $19.12 \pm 3.27$ at day 7 , which was higher than our previous report using the Iodogen method [22], verifying the ATE method has a better stability in
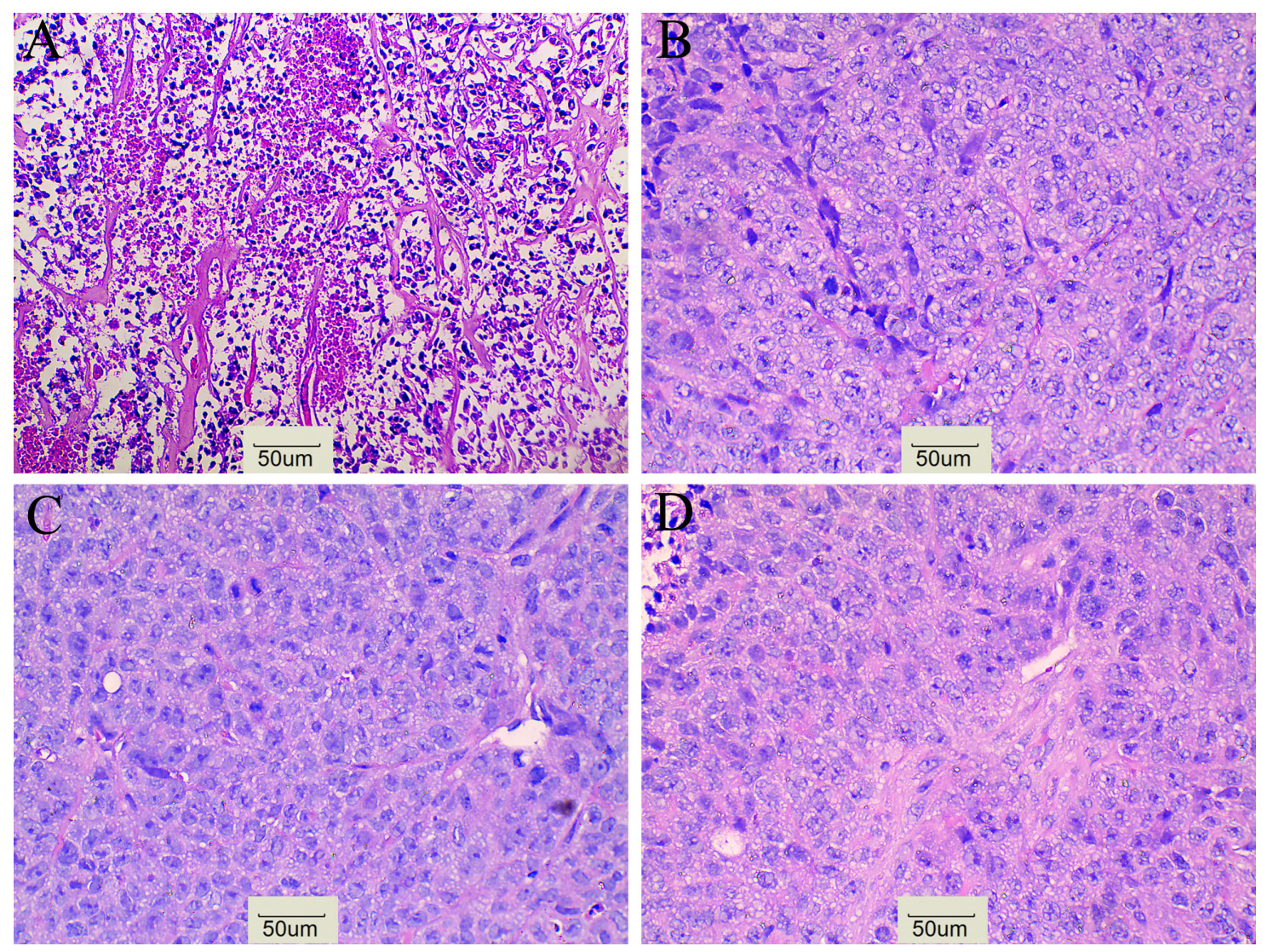

Figure 6: H\&E staining. (A) ${ }^{131} \mathrm{I}-\mathrm{AC} 133.1 \mathrm{mAb}$ group, (B) ${ }^{131} \mathrm{I}-\mathrm{IgG1}$ group, (C) AC133.1 mAb group, (D) Saline group. H\&E staining shows a large necrosis in ${ }^{131} \mathrm{I}-\mathrm{AC} 133.1 \mathrm{mAb}$ group, while no obvious necrosis were observed in control groups $(\times 200)$. 
vivo. A sufficient radiation dose delivered to the tumor is important for the curative effect, and tumor responses will depend on the amount of tissue being irradiated as well as the radiation sensitivity of the tissue, because solid tumors typically require 3,500-10,000 cGy for a meaningful response [31], consistent with our result $(5,966.34 \pm 54.90$ cGy).

A number of biomarkers of colorectal CSCs have been identified, and it is thought that only a small subset of CD133(+) cells were colorectal CSCs. CD133 is a commonly used colorectal CSC marker, and can be used in combination with other markers to screen the purity of CSCs. Haraguchi et al. [32] identified cancer initiating cells were more likely to be from a CD133(+) CD44(+) population compared with $\mathrm{CD} 133(+)$ or CD44(+) cells alone. For RIT, the therapeutic effect was highly relevant to the radionuclide. ${ }^{131} \mathrm{I}$ has a low linear energy transfer $(\mathrm{LET}=0.1-1.0 \mathrm{kev} / \mu \mathrm{m})$, thus producing non-specific exposure to normal organs as a result of the cross-fire effect. Alpha particles have high linear energy transfer, and lethal effect does not rely completely on tissue oxygen; thus is has been commonly used for RIT in recent years [33-35]. Furthermore, the poor pharmacokinetic properties caused by the high molecular weight of mAbs $(\sim 150 \mathrm{kDa})$ limits the effects of RIT; however, progress in genetic engineering antibody, and strategies including pretargeted technology [29], fractionated RIT [31, 36], and RIT combination with other therapeutic modalities such as chemotherapy, mAb based biotherapy, and customized radiolabeled antibody cocktails might enhance the effect of RIT [37-42]. In conclusion, our results indicate that $\mathrm{mAb}$-conjugated RIT successfully retards tumor progression, while enhancing median survival time by targeting CD133(+) CSCs in a mouse model of colon cancer.

\section{MATERIALS AND METHODS}

\section{Ethics statement}

All animal procedures were performed according to a protocol approved by the Institutional Animal Care and Use Committee of HuaZhong University of Science and Technology.

\section{Mab and cells}

AC133.1 mAb preparations were produced from ascites grown from $\mathrm{BALB} / \mathrm{c}$ mice that received intraperitoneal injections of the appropriate hybridoma (HB-12346). AC133.1 mAb is an IgG1 murine monoclonal antibody purified by protein A/G. HCT116 cells were purchased from the Cell Bank of the Chinese Academy of Sciences, grown in RPMI1640 and cultured in medium supplemented with $10 \%(\mathrm{v} / \mathrm{v}) \mathrm{FBS}$ at $37^{\circ} \mathrm{C}$ in a humidified atmosphere with $5 \% \mathrm{CO}_{2}$.

\section{Antibody labeling using the ATE method}

ATE was synthesized according to a previous report [43]. For this procedure, $0.9 \mu \mathrm{l}$ ATE was placed into a reaction vial fitted with a septum containing 100 $\mu \mathrm{l} 1 \% \mathrm{HOAC} / \mathrm{MeOH}, 10 \mu \mathrm{N}$-chlorosuccinimide in $\mathrm{MeOH}$, and $10 \mu \mathrm{l}$ of phosphate buffered saline (PBS). The desired quantity of $\mathrm{Na}^{131} \mathrm{I}$ was added (about 38.48 $\mathrm{MBq}$ ), and after $10 \mathrm{~min}$ at $\mathrm{RT}$ the reaction was quenched by the addition of $10 \mu \mathrm{l}$ of $0.72 \mathrm{mg} / \mathrm{ml}$ aqueous solution of $\mathrm{NaHSO}_{3}$ solution. The intermediate product, ${ }^{131} \mathrm{I}-\mathrm{SIB}$, was purified by sepax positive-phase semipreparative column (HPLC), and ${ }^{131} \mathrm{I}-\mathrm{SIB}$ was dried by $\mathrm{N}_{2}$. Then, 50 $\mu \mathrm{l}$ of $\mathrm{AC} 133.1 \mathrm{mAb}$ was dissolved in $50 \mu \mathrm{l}$ borate buffer $(\mathrm{pH}=8.7)$ and then added into the above dried ${ }^{131} \mathrm{I}-\mathrm{SIB}$ at RT for $30 \mathrm{~min}$ with constant shaking. The reaction was terminated by the addition of $300 \mu \mathrm{l}$ of $0.2 \mathrm{M}$ glycine. The crude radiolabeled compound was purified by a sephadex G-25 column using PBS as the eluent.

\section{Equilibrium dissociation constant determination}

The equilibrium dissociation constant for the labeled AC133.1 mAb preparations to HCT116 were determined using a cell-saturated assay. Briefly, $1 \times 10^{6}$ cells/well were grown to confluence in 12-well plates, serial dilutions of each labeled AC133.1 mAb preparations were added to each well in triplicate after $150 \mu \mathrm{l} 1 \% \mathrm{BSA} / \mathrm{PBS}$ was added in advance and incubated for $30 \mathrm{~min}$, and then coincubated at $37^{\circ} \mathrm{C}$ for $4 \mathrm{~h}$. The wells were washed 3 times with $1 \% \mathrm{BSA} / \mathrm{PBS}$ and $0.1 \mathrm{M} \mathrm{NaOH}$ solution was used to crack cells. The supernatant was collected, precipitated separately and radioactivity measured using an automated $\gamma$ counter. Non-specific cell binding was determined by adding 500-fold unlabeled AC133.1 mAb, incubated for $30 \mathrm{~min}$ and then adding the above labeled AC133.1 $\mathrm{mAb}$. The percentage of specific binding was calculated by subtracting the nonspecific binding from total binding. Equilibrium dissociation constants were analyzed using a computer program.

\section{Serum stability}

${ }^{131} \mathrm{I}-\mathrm{AC} 133.1 \mathrm{mAb}$ was mixed with an appropriate volume $\mathrm{FBS}$ at $4^{\circ} \mathrm{C}$, and the radiochemical purity was calculated at different time points $(0,1,3$, and $7 \mathrm{~d})$.

\section{Tumor model}

Male athymic mice (nu/nu genotype, BALB/c background) of at least 8 weeks of age and weighing 20-24 g were purchased from the Beijing HuaFuKang Company (Beijing, China). The HCT116 colonic tumor model was established by the injection of $2 \times 10^{6}$ cells in $100 \mu \mathrm{l}$ PBS into the lower right limbs. Tumor volumes were calculated as

$(\text { short dimension })^{2} \times$ long dimension $/ 2$ 
Animals were randomized by tumor volume, and therapeutic trials were initiated when the tumor diameter was approximately $4 \mathrm{~mm}$.

\section{RIT experiments}

Two therapy studies were performed using ${ }^{131} \mathrm{I}-$ AC133.1 mAb. The first therapy study was designed to assess the MTD in HCT116-bearing nude mice. The MTD, corresponding to the highest dose at which weight loss did not exceed $20 \%$ of initial weight, was determined by monitoring the weight and health status of tumor-bearing nude mice injected intravenously with increasing doses of ${ }^{131} \mathrm{I}-\mathrm{AC} 133.1 \mathrm{mAb}$. Nine groups were treated with 7.40 , $9.25,11.10,12.95,14.80,16.65,18.50,20.35$ or 22.20 ${ }^{131} \mathrm{I}-\mathrm{AC} 133.1 \mathrm{mAb}$, respectively (each dose was tested in six mice). Because organ damage may not develop immediately, animals were monitored for an addition 30 days. The second experiment studied the therapeutic efficacy of RIT (six mice per group). To ensure therapeutic efficacy, the ${ }^{131} \mathrm{I}-\mathrm{AC} 133.1 \mathrm{mAb}$ group received the MTD in a volume of $100 \mu \mathrm{l}$. For the AC133.1 mAb group, the amount of antibody was calculated from the radiospecific activity of the radiolabeled compound. Unrelated IgG1 was used as the isotype control. Animals were housed individually, and bedding was changed at $48 \mathrm{~h}$ and 96 $\mathrm{h}$ and twice weekly to reduce nonspecific background exposure. Tumor sizes were measured every 4-5 days and health status was observed daily. Mice in the RIT trials were excluded when weight loss exceeded $20 \%$ of starting weight, or the tumor volume was greater than $750 \mathrm{~mm}^{3}$ [44].

An antitumor effect was expressed as tumor VDT, which was calculated using the following equation: VDT $=\left(\mathrm{T}-\mathrm{T}_{0}\right) \times \log 2 / \log \left(\mathrm{V} / \mathrm{V}_{0}\right)$, where $\mathrm{T}-\mathrm{T}_{0}$ indicates the length of time between two measurements and $\mathrm{V}_{0}$ and $\mathrm{V}$ denote the tumor volume at two points of measurements [45]. In addition, survival curves were constructed.

\section{Biodistribution and radiation dosimetry}

Tissue distribution studies were initiated when the mean tumor diameter reached $0.8-1.0 \mathrm{~cm}$ and mice were then injected intravenously with about $7.40 \mathrm{MBq}{ }^{131} \mathrm{I}-$ AC133.1 mAb. On days 1, 3, 5, 7, and 9 after injection, groups of 4 animals were euthanized, and tissues (including blood, tumor, muscle, femoral bone, spleen, kidney, liver, stomach, large intestine, lung, heart, thyroid, brain) were obtained and weighed. Results are expressed as a percentage of the injected dose. The radiation absorbed dose was calculated from the biodistribution data, and the percentage injected dose per gram $(\% \mathrm{ID} / \mathrm{g})$ value was corrected for the radiation decay of ${ }^{131} \mathrm{I}$ and converted to $\mu \mathrm{ci} / \mathrm{g}$. The cumulative activity in tumors ( $\mu \mathrm{ci}-$ $\mathrm{h} / \mathrm{g}$ ) was calculated from the area under the resultant $\mu \mathrm{ci} / \mathrm{g}$ curves using the trapezoid integration method. A uniform distribution of ${ }^{131} \mathrm{I}$ in tissues was assumed. The radiation absorbed dose in rads (cGy) received by tumor was calculated by multiplying its cumulative activity by the equilibrium absorbed dose constant $(0.4313 \mathrm{~g}-\mathrm{rad} / \mu \mathrm{ci}-\mathrm{h})$ of ${ }^{131} \mathrm{I}$ [28]. Because of the low absorbed fractions of ${ }^{131} \mathrm{I}$ $\gamma$-rays in small tissues such as those in BALB/c athymic mice, the dose due to $\gamma$ exposure was not included.

\section{Flow cytometry, western blot, $H \& E$, and ki67 staining}

For flow cytometry, marginal tumor tissues not including necrotic tissues or blood streaks were sheared, washed three times with saline, cut into slices, digested with collagenase IV for $1 \mathrm{~h}$ at $37^{\circ} \mathrm{C}$, filtered through a $70-\mu \mathrm{m}$ screen mesh, then resuspended as a monolayer suspension. Then, $3 \mu$ APC-CD133/1(MiltenyiBiotec) was added and incubated at $4^{\circ} \mathrm{C}$ for $30 \mathrm{~min}$, centrifuged for $5 \mathrm{~min}$ at 110 $\mathrm{g}$, and then resuspended in $300 \mu \mathrm{l}$ PBS for sample testing.

After sacrificing the mice, the tumor tissues were removed immediately and ground completely. After centrifugation $\left(400 \times \mathrm{g}, 4^{\circ} \mathrm{C}\right)$ for $5 \mathrm{~min}$, the supernatant was collected to quantify the protein using the Bradford protein assay kit (Thermo Fisher). Protein was separated by sodium dodecyl sulfate-polyacrylamide gel electrophoresis and then electroblotted onto a polyvinylidenedifluoride membrane (Millipore, Billerica, MA, USA). The membrane was incubated with mAb (Miltenyi Biotec, Bergisch Gladbach, Germany) overnight at $4^{\circ} \mathrm{C}$. $\beta$-actin was used as a control. Each experiment was performed in triplicate.

For H\&E staining, tumor tissues were fixed in $4 \%$ paraformaldehyde for 10-12 h, embedded in paraffin, passed through a serial process of dewaxing, dyeing, hydration and drying.

For Ki67 staining, an antigen retrieval kit from MiltenyiBiotec was used according to the manufacturer's specifications. Endogenous peroxidase was blocked with $3 \%$ hydrogen peroxide in PBS and incubated with aproteinblocking solution containing PBS ( $\mathrm{pH}$ 7.5). Samples were incubated with a 1:200 dilution of Ki67, incubated in diaminobenzidine, mounted on glass slides with cover slips.

\section{Statistical analysis}

Quantitative data were expressed as mean \pm standard deviation (SD) or percentage when appropriate. All data were analyzed with the One-way ANOVA or nonparametric tests (Mann-Whitney $U$-test for comparison of 2 groups and the Kruskal-Wallis test for comparison of multiple groups). Survival was calculated using Kaplan-Meier curves. $P<$ 0.05 was considered statistically significant.

\section{Abbreviations}

CSCs: cancer stem cells; RIT: radioimmunotherapy; mAb: monoclonal antibody; MTD: maximum tolerated dose; CRC: colorectal cancer; WB: western blot; H\&E: hematoxylin eosin; ADCC: antibody dependent 
cellular cytotoxicity; ROS: reactive oxygen species; LET: linger energy transfer; FBS: fetal bovine serum; RT: room temperature; HPLC: high performance liquid chromatography; PBS: phosphate buffered saline; SD: standard deviation.

\section{ACKNOWLEDGMENTS}

We are grateful to all members of our laboratory for their helpful discussions and suggestions.

\section{CONFLICTS OF INTEREST}

The authors declare no other potential conflicts of interest relevant to this article exist.

\section{GRANT SUPPORT}

This study was supported by the National Natural Science Foundation of China (81071178, 81371599).

\section{REFERENCES}

1. Torre LA, Bray F, Siegel RL, Ferlay J, Lortet-Tieulent J, Jemal A. Global cancer statistics, 2012. CA Cancer J Clin. 2015; 65:87-108.

2. Chen $\mathrm{W}$, Zheng $\mathrm{R}$, Zeng $\mathrm{H}$, Zhang $\mathrm{S}$. The updated incidences and mortalities of major cancers in China, 2011. Chin J Cancer. 2015; 34:502-507.

3. Siegel R, Desantis C, Jemal A. Colorectal cancer statistics, 2014. CA Cancer J Clin. 2014; 64:104-117.

4. Machii R, Saika K. Five-year relative survival rate of colon cancer in the USA, Europe and Japan. Jpn J Clin Oncol. 2014; 44:105-106.

5. Mitra A, Mishra L, Li S. EMT, CTCs and CSCs in tumor relapse and drug-resistance. Oncotarget. 2015; 6:1069710711. doi: 10.18632/oncotarget.4037.

6. Janikova M, Skarda J. Differentiation pathways in carcinogenesis and in chemo- and radioresistance. Neoplasma. 2012; 59:6-17.

7. Dawood S, Austin L, Cristofanilli M. Cancer stem cells: implications for cancer therapy. Oncology (Williston Park). 2014; 28:1101-1107, 1110.

8. Bonnet D, Dick JE. Human acute myeloid leukemia is organized as a hierarchy that originates from a primitive hematopoietic cell. Nat Med. 1997; 3:730-737.

9. Fanali C, Lucchetti D, Farina M, Corbi M, Cufino V, Cittadini A, Sgambato A. Cancer stem cells in colorectal cancer from pathogenesis to therapy: controversies and perspectives. World J Gastroenterol. 2014; 20:923-942.

10. Singh SK, Clarke ID, Terasaki M, Bonn VE, Hawkins C, Squire J, Dirks PB. Identification of a cancer stem cell in human brain tumors. Cancer Res. 2003; 63:5821-5828.
11. Singh SK, Hawkins C, Clarke ID, Squire JA, Bayani J, Hide T, Henkelman RM, Cusimano MD, Dirks PB. Identification of human brain tumour initiating cells. Nature. 2004; 432:396-401.

12. O'Brien CA, Pollett A, Gallinger S, Dick JE. A human colon cancer cell capable of initiating tumour growth in immunodeficient mice. Nature. 2007; 445:106-110.

13. Zhang PY, Yang YJ, Xue Y, Fu J, Zhang CX, Wang Y, Yang Y, Shi H. Cancer stem cells: targeting tumors at the source. Eur Rev Med Pharmacl Sci. 2015; 19:1821-1828.

14. Qureshi-Baig K, Ullmann P, Haan S, Letellier E. TumorInitiating Cells: a criTICal review of isolation approaches and new challenges in targeting strategies. Mol Cancer. 2017; 16:40.

15. Jandl T, Revskaya E, Jiang Z, Harris M, Dorokhova O, Tsukrov D, Casadevall A, Dadachova E. Melanoma stem cells in experimental melanoma are killed by radioimmunotherapy. Nucl Med Biol. 2013; 40:177-181.

16. Leyton JV, Gao C, Williams B, Keating A, Minden M, Reilly RM. A radiolabeled antibody targeting CD123(+) leukemia stem cells - initial radioimmunotherapy studies in NOD/SCID mice engrafted with primary human AML. Leuk Res Rep. 2015; 4:55-59.

17. Al-Ejeh F, Shi W, Miranda M, Simpson PT, Vargas AC, Song S, Wiegmans AP, Swarbrick A, Welm AL, Brown MP, Chenevix-Trench G, Lakhani SR, Khanna KK. Treatment of triple-negative breast cancer using anti-EGFR-directed radioimmunotherapy combined with radiosensitizing chemotherapy and PARP inhibitor. J Nucl Med. 2013; 54:913-921.

18. Karagiannis TC. Comparison of different classes of radionuclides for potential use in radioimmunotherapy. Hell J Nucl Med. 2007; 10:82-88.

19. Chen J, Wang M, Joyce A, DeFranco D, Kavosi M, Xu X, O'Hara DM. Comparison of succinimidyl [(125)I] iodobenzoate with iodogen iodination methods to study pharmacokinetics and ADME of biotherapeutics. Pharm Res. 2014; 31:2810-2821.

20. Mohammadnejad J, Rasaee MJ, Babaei MH, Paknejad M, Hasan ZM, Salouti M, Gandomkar M, Sadri K. Radioimmunotherapy of MCF7 breast cancer cell line with 131I-PR81 monoclonal antibody against MUC1: comparison of direct and indirect radioiodination methods. Hum Antibodies. 2010; 19:15-25.

21. Santos JS, Muramoto E, Colturato MT, Siva CP, Araujo EB. Radioiodination of proteins using prosthetic group: a convenient way to produce labelled proteins with in vivo stability. Cell Mol Bio (Noisy-le-Grand). 2002; 48:735-739.

22. Lang J, Lan X, Liu Y, Jin X, Wu T, Sun X, Wen Q, An R. Targeting cancer stem cells with an 131I-labeled anti-AC133 monoclonal antibody in human colorectal cancer xenografts. Nucl Med Biol. 2015; 42:505-512.

23. Leyton JV, Hu M, Gao C, Turner PV, Dick JE, Minden M, Reilly RM. Auger electron radioimmunotherapeutic agent 
specific for the CD123+/CD131- phenotype of the leukemia stem cell population. J Nucl Med. 2011; 52:1465-1473.

24. Vaiopoulos AG, Kostakis ID, Koutsilieris M, Papavassiliou AG. Colorectal cancer stem cells. Stem cells. 2012; 30:363-371.

25. Bellizzi A, Sebastian S, Ceglia P, Centonze M, Divella R, Manzillo EF, Azzariti A, Silvestris N, Montemurro S, Caliandro C, De Luca R, Cicero G, Rizzo S, et al. Co-expression of $\mathrm{CD} 133(+) / \mathrm{CD} 44(+)$ in human colon cancer and liver metastasis. J Cell Physio. 2013; 228:408-415.

26. Yu Z, Pestell TG, Lisanti MP, Pestell RG. Cancer stem cells. Int J Biochem Cell Biol. 2012; 44:2144-2151.

27. Ricci-Vitiani L, Lombardi DG, Pilozzi E, Biffoni M, Todaro M, Peschle C, De Maria R. Identification and expansion of human colon-cancer-initiating cells. Nature. 2007; 445:111-115.

28. Schuster JM, Garg PK, Bigner DD, Zalutsky MR. Improved therapeutic efficacy of a monoclonal antibody radioiodinated using N-succinimidyl-3-(tri-n-butylstannyl) benzoate. Cancer Res. 1991; 51:4164-4169.

29. Navarro-Teulon I, Lozza C, Pelegrin A, Vives E, Pouget JP. General overview of radioimmunotherapy of solid tumors. Immunotherapy. 2013; 5:467-487.

30. Kraeber-Bodere F, Rousseau C, Bodet-Milin C, Mathieu C, Guerard F, Frampas E, Carlier T, Chouin N, Haddad F, Chatal JF, Faivre-Chauvet A, Cherel M, Barbet J. Tumor immunotargeting using innovative radionuclides. Int J Mol Sci. 2015; 16:3932-3954.

31. Larson SM, Carrasquillo JA, Cheung NK, Press OW. Radioimmunotherapy of human tumours. Nat Rev Cancer. 2015; 15:347-360.

32. Haraguchi N, Ohkuma M, Sakashita H, Matsuzaki S, Tanaka F, Mimori K, Kamohara Y, Inoue H, Mori M. CD133+CD44+ population efficiently enriches colon cancer initiating cells. Ann Surg Oncol. 2008; 15:2927-2933.

33. Aghevlian S, Boyle AJ, Reilly RM. Radioimmunotherapy of cancer with high linear energy transfer (LET) radiation delivered by radionuclides emitting alpha-particles or Auger electrons. Adv Drug Deliv Rev.2015.

34. Seidl C. Radioimmunotherapy with alpha-particle-emitting radionuclides. Immunotherapy. 2014; 6:431-458.

35. Tomblyn MB, Katin MJ, Wallner PE. The new golden era for radioimmunotherapy: not just for lymphomas anymore. Cancer Control. 2013; 20:60-71.
36. Goldenberg DM, Chang CH, Rossi EA, J W, McBride and Sharkey RM. Pretargeted molecular imaging and radioimmunotherapy. Theranostics. 2012; 2:523-540.

37. Hanaoka H, Kuroki M, Yamaguchi A, Achmad A, Iida Y, Higuchi T, Oriuchi N, Tsushima Y, Endo K. Fractionated radioimmunotherapy with (9)(0)Y-labeled fully human anti-CEA antibody. Cancer Biother Radiopharm. 2014; 29:70-76.

38. Heyerdahl H, Abbas N, Brevik EM, Mollatt C, Dahle J. Fractionated therapy of HER2-expressing breast and ovarian cancer xenografts in mice with targeted alpha emitting 227Th-DOTA-p-benzyl-trastuzumab. PloS one. 2012; 7:e42345.

39. Lindenblatt D, Fischer E, Cohrs S, Schibli R, Grunberg J. Paclitaxel improved anti-L1CAM lutetium-177 radioimmunotherapy in an ovarian cancer xenograft model. EJNMMI Res. 2014; 4:54.

40. Vassileva V, Rajkumar V, Mazzantini M, Robson M, Badar A, Sharma S, Arstad E, Hochhauser D, Lythgoe MF, Kinghorn J, Boxer GM, Pedley RB. Significant Therapeutic Efficacy with Combined Radioimmunotherapy and Cetuximab in Preclinical Models of Colorectal Cancer. J Nucl Med. 2015; 56:1239-1245.

41. Pasternack JB, Domogauer JD, Khullar A, Akudugu JM, Howell RW. The advantage of antibody cocktails for targeted alpha therapy depends on specific activity. J Nucl Med. 2014; 55:2012-2019.

42. Liang W, Ni Y, Chen F. Tumor resistance to vascular disrupting agents: mechanisms, imaging, and solutions. Oncotarget. 2016; 7:15444-15459. doi: 10.18632/oncotarget.6999.

43. Vaidyanathan G, Zalutsky MR. Preparation of $\mathrm{N}$-succinimidyl 3-[*I]iodobenzoate: an agent for the indirect radioiodination of proteins. Nat Protoc. 2006; 1:707-713.

44. Zacchetti A, Martin F, Luison E, Coliva A, Bombardieri E, Allegretti M, Figini M, Canevari S. Antitumor effects of a human dimeric antibody fragment 131I-AFRA-DFM5.3 in a mouse model for ovarian cancer. J Nucl Med. 2011; 52:1938-1946.

45. Ozono S, Miyao N, Igarashi T, Marumo K, Nakazawa H, Fukuda M, Tsushima T, Tokuda N, Kawamura J, Murai M. Tumor doubling time of renal cell carcinoma measured by CT: collaboration of Japanese Society of Renal Cancer. Jpn J Clin Oncol. 2004; 34:82-85. 